\title{
Review \\ Current Status of Endolysin-Based Treatments against Gram-Negative Bacteria
}

\author{
Marco Túlio Pardini Gontijo * (D), Genesy Perez Jorge and Marcelo Brocchi \\ Departamento de Genética, Evolução, Microbiologia e Imunologia, Instituto de Biologia, Universidade Estadual \\ de Campinas (UNICAMP), Rua Monteiro Lobato 255, Campinas 13083-862, Brazil; \\ g211546@dac.unicamp.br (G.P.J.); mbrocchi@unicamp.br (M.B.) \\ * Correspondence: m264546@dac.unicamp.br; Tel.: +55-11-9-8577-7682
}

Citation: Gontijo, M.T.P.; Jorge, G.P.; Brocchi, M. Current Status of Endolysin-Based Treatments against Gram-Negative Bacteria. Antibiotics 2021, 10, 1143. https://doi.org/ 10.3390/antibiotics 10101143

Academic Editor: Hongping Wei

Received: 4 June 2021

Accepted: 21 July 2021

Published: 22 September 2021

Publisher's Note: MDPI stays neutral with regard to jurisdictional claims in published maps and institutional affiliations.

Copyright: (C) 2021 by the authors. Licensee MDPI, Basel, Switzerland. This article is an open access article distributed under the terms and conditions of the Creative Commons Attribution (CC BY) license (https:// creativecommons.org/licenses/by/ $4.0 /)$.

\begin{abstract}
The prevalence of multidrug-resistant Gram-negative bacteria is a public health concern. Bacteriophages and bacteriophage-derived lytic enzymes have been studied in response to the emergence of multidrug-resistant bacteria. The availability of tRNAs and endolysin toxicity during recombinant protein expression is circumvented by codon optimization and lower expression levels using inducible pET-type plasmids and controlled cultivation conditions, respectively. The use of polyhistidine tags facilitates endolysin purification and alters antimicrobial activity. Outer membrane permeabilizers, such as organic acids, act synergistically with endolysins, but some endolysins permeate the outer membrane of Gram-negative bacteria per se. However, the outer membrane permeation mechanisms of endolysins remain unclear. Other strategies, such as the co-administration of endolysins with polymyxins, silver nanoparticles, and liposomes confer additional outer membrane permeation. Engineered endolysins comprising domains for outer membrane permeation is also a strategy used to overcome the current challenges on the control of multidrug-resistant Gram-negative bacteria. Metagenomics is a new strategy for screening endolysins with interesting antimicrobial properties from uncultured phage genomes. Here, we review the current state of the art on the heterologous expression of endolysin, showing the potential of bacteriophage endolysins in controlling bacterial infections.
\end{abstract}

Keywords: nosocomial pathogen; bacteriophage; enzybiotic; peptide tag; bactericidal activity; biocontrol; antibiotic substitute

\section{Introduction}

The indiscriminate use of antibiotics led to the emergence of antibiotic-resistant bacteria [1-3]. Antimicrobial resistance, the faster run of microbial evolution, and the failure in the development of antimicrobial drugs are health, economic, and social concerns $[4,5]$. Multidrug-resistant Gram-negative bacteria are a public health concern due to the low permeability of the outer membrane and the ease of exchange of antibiotic resistance genes [6]. Antimicrobial resistance in Gram-negative bacteria can arise from the mutation of genes carried in the chromosome or result from the acquisition, through horizontal gene transfer, of plasmids and transposons containing antibiotic resistance genes [7,8]. The main antimicrobial resistance mechanisms include antibiotic-inactivating enzymes, efflux pumps, and permeability or target modifications $[9,10]$. The most common multidrug-resistant Gramnegative bacteria are Acinetobacter spp., Bordetella pertussis, Campylobacter spp., Citrobacter spp., Enterobacter spp., Escherichia coli, Klebsiella spp., Salmonella spp., Serratia marcescens, Shigella spp., Yersinia spp., Haemophilus influenzae, Helicobacter pylori, Legionella pneumophila, Neisseria spp., Pseudomonas aeruginosa, and Vibrio cholerae [11].

Frederick Twort discovered bacteriophages (or phages) in 1915 [12]. Nonetheless, bacteriophages were first used in the biocontrol of bacteria by Felix d'Herelle [13]. Bacteriophages have been the study center of great scientific discoveries, such as gene regulation [14] and the CRISPR-Cas9 system [15], both Nobel-Prize-winning studies. The 
interest in bacteriophages has increased since the late 20th century as a response to the emergence of multidrug-resistant bacteria [16-19]. The lytic replication of bacteriophages requires the insertion of phage's genetic material into the bacterial host, resulting in virion multiplication and, for most bacteriophages, the expression of endolysins, proteins that cause cell lysis throughout the disruption of peptidoglycan [20]. Cell lysis is caused by phage endolysins [21-23] and other accessory proteins such as holins and pinholins, that act in the cytoplasmic membrane [24-26], and spanins, that form junctions between the inner and outer membranes of Gram-negative bacteria [27].

Phage endolysins are subdivided into (I) glucosaminidases; (II) lysozymes or muramidases; (III) lytic transglycosylases; (IV) endopeptidases; and (V) amidases; depending on the peptidoglycan disruption mechanism [28-30]. The cleavage of a conserved structure such as the peptidoglycan points to endolysins as promising antimicrobials against multidrug-resistant Gram-negative bacteria. Bacteriophage endolysins are active from the inside of the cell. Bacteriophage-encoded accessory proteins help cytoplasmatic membrane export to reach the peptidoglycan [26,27]. Despite some advantages over the use of bacteriophages, such as broad-spectrum specificity and no report of bacterial resistance, the exogenous application of endolysins against Gram-negative bacteria is difficult due to the low permeability of the outer membrane [31] and some endolysins require additional strategies to permeate the outer membrane (Figure 1).
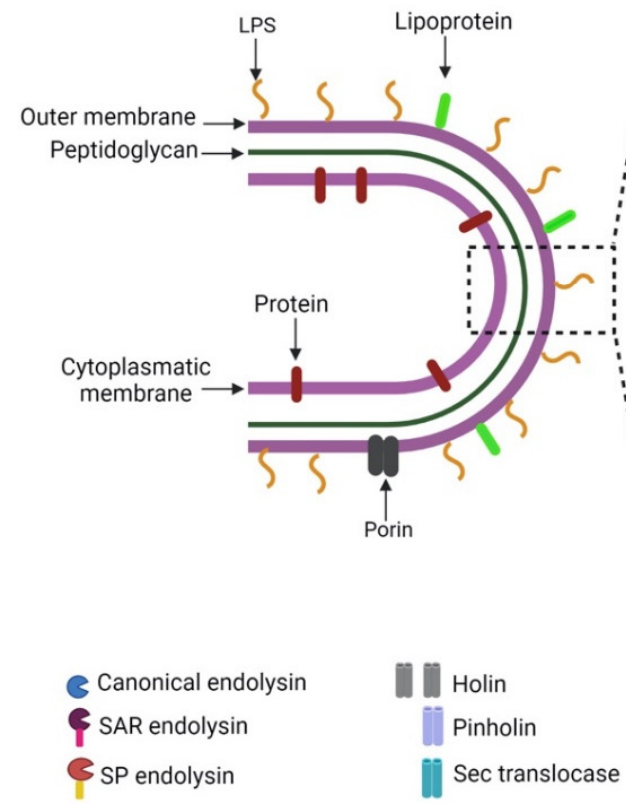

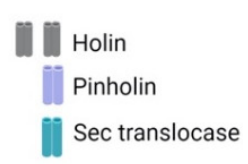

Mechanisms of peptidoglycan hydrolysis

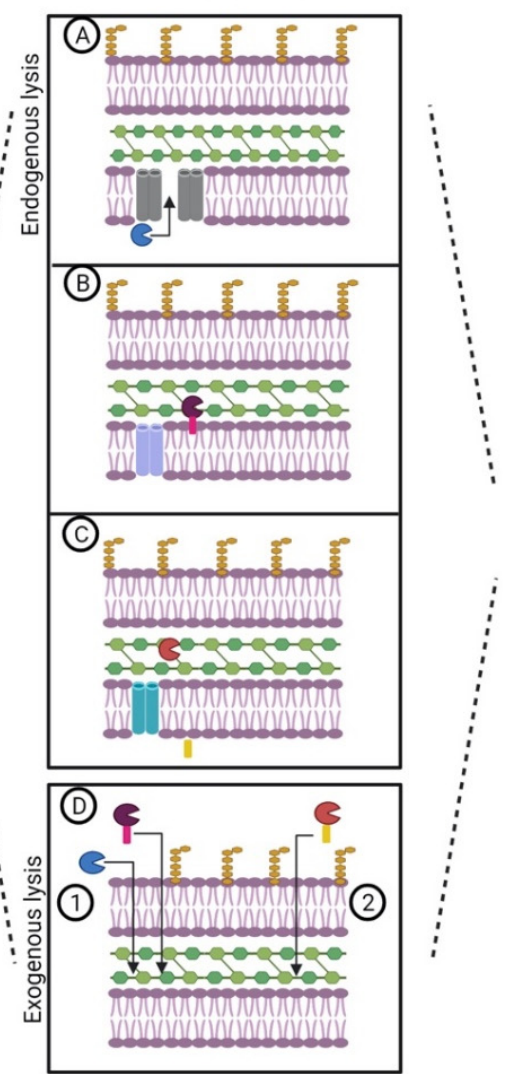

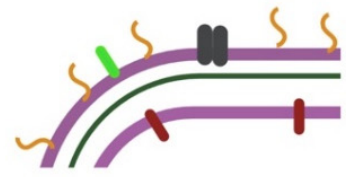

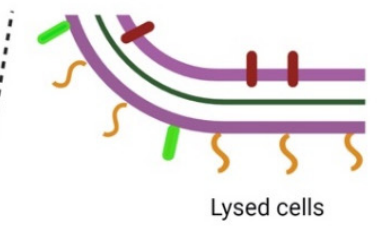
(1) Permeation in the presence of
organic acids, EDTA and others

(2) Permeation due to intrinsic properties of the endolysin

Figure 1. Mechanisms of peptidoglycan access of endolysins that act on Gram-negative bacteria: (A) endogenous lysis mediated by holins; (B) endogenous lysis mediated by pinholins; (C) endogenous lysis mediated by bacterial Sec translocases; (D) exogenous lysis.

Several reviews approached bacterial therapy with bacteriophages [32-35]; however, the knowledge on the application of endolysins against Gram-negative bacteria is still scarce [29]. In this context, this review provides a comprehensive overview of the current 
status of research on endolysin-based treatments against Gram-negative bacteria, including expression vectors variety, cell systems used for protein expression, expression induction particularities, purification strategies, and antibacterial assay results. This review comprises a critical analysis of the most relevant papers in the last decade that focuses on endolysin heterologous expression.

\section{Availability of tRNAs and Protein Toxicity Limit Endolysin Heterologous Expression}

The heterologous expression of proteins finds two main difficulties that affect recombinant endolysin production: (I) the availability of tRNAs depending on the species in which the endolysin targets; and (II) protein toxicity [36]. Both of these situations result in little or no expression of the heterologous protein [37].

The availability of tRNAs, however, is circumvented by codon optimization strategies $[38,39]$. Most of the work on the heterologous expression of endolysins is conducted using the E. coli expression system (Table 1) and codon usage in this species is widely known [40,41]. Ph2119 endolysin, encoded by the Thermus scotoductus MAT2119 bacteriophage, possessed a significant number of rare codons for E. coli. Nevertheless, the codon-optimized gene was successfully introduced and expressed in E. coli and the purified enzyme showed high lytic activity toward Gram-positive bacteria and, to a lower degree, against Gram-negative pathogens such as E. coli, S. marcescens, Pseudomonas fluorescens, and Salmonella enterica [42]. The codon usage bias is more pronounced among Gram-negative and Gram-positive bacteria [43]. The codon preference and the abundance of tRNAs within any set of species is variable and codon-anticodon adaptation was reported in the relationship between phages and their host cells [44]. Closely related species, such as E. coli and S. enterica, have similar patterns of codon usage; however, different codons are preferred by Helicobacter pylori, also a Gram-negative bacterium [45]. These features highlight the requirement for codon optimization for a proper E. coli expression system even for endolysins encoded in the genomes of bacteriophages infecting closely related species.

Protein toxicity is an important feature of endolysins once the main goal of bacteriophagederived lytic enzymes is an antibacterial activity. Toxic proteins, such as endolysins, affect the viability of the host cell during transformation and, in particular, during protein expression. Several authors have used pET plasmids (Table 1), which are regulated by the T7 bacteriophage promoter. The use of pET-type plasmids is advantageous due to: (I) high expression levels, resulting in proteins that can represent approximately 50\% of the total protein content [37,41]; and (II) the maintenance of genes transcriptionally silent until induction [41,46]. The target endolysins are cloned in pET-type plasmids and transferred to E. coli strain (Figure 2A,B) comprising a chromosomal copy of the T7 RNA polymerase gene under the control of the lacUV5 promoter (E. coli strains BL21, BL21(DE3), BL21(DE3) pLysS, and others), which is induced in the presence of IsoPropyl$\beta$-D-1-ThioGalactopyranoside (IPTG) [46]. Other levels of controlled expression are the decrease in the protein expression using lower temperatures and lower concentrations of the IPTG inducer (Figure 2C) [31,47-49].

Plotka et al. (2014) [42] observed that the overexpression of the synthetic gene of Ph2119 endolysin resulted in protein leakage. Nevertheless, decreasing incubation temperature to $30{ }^{\circ} \mathrm{C}$ was sufficient to reduce protein toxicity to E. coli cells and to decrease the inhibition of bacterial growth. Alternatively, several authors have used optimal E. coli growth temperatures $\left(37^{\circ} \mathrm{C}\right)$ and incubation times inferior to $5 \mathrm{~h}$ and obtained recombinant endolysins with promising antibacterial activity [50-53]. Antonova et al. (2019) [54] suggested little internal cell membrane penetration or insignificant lysis during protein expression. 


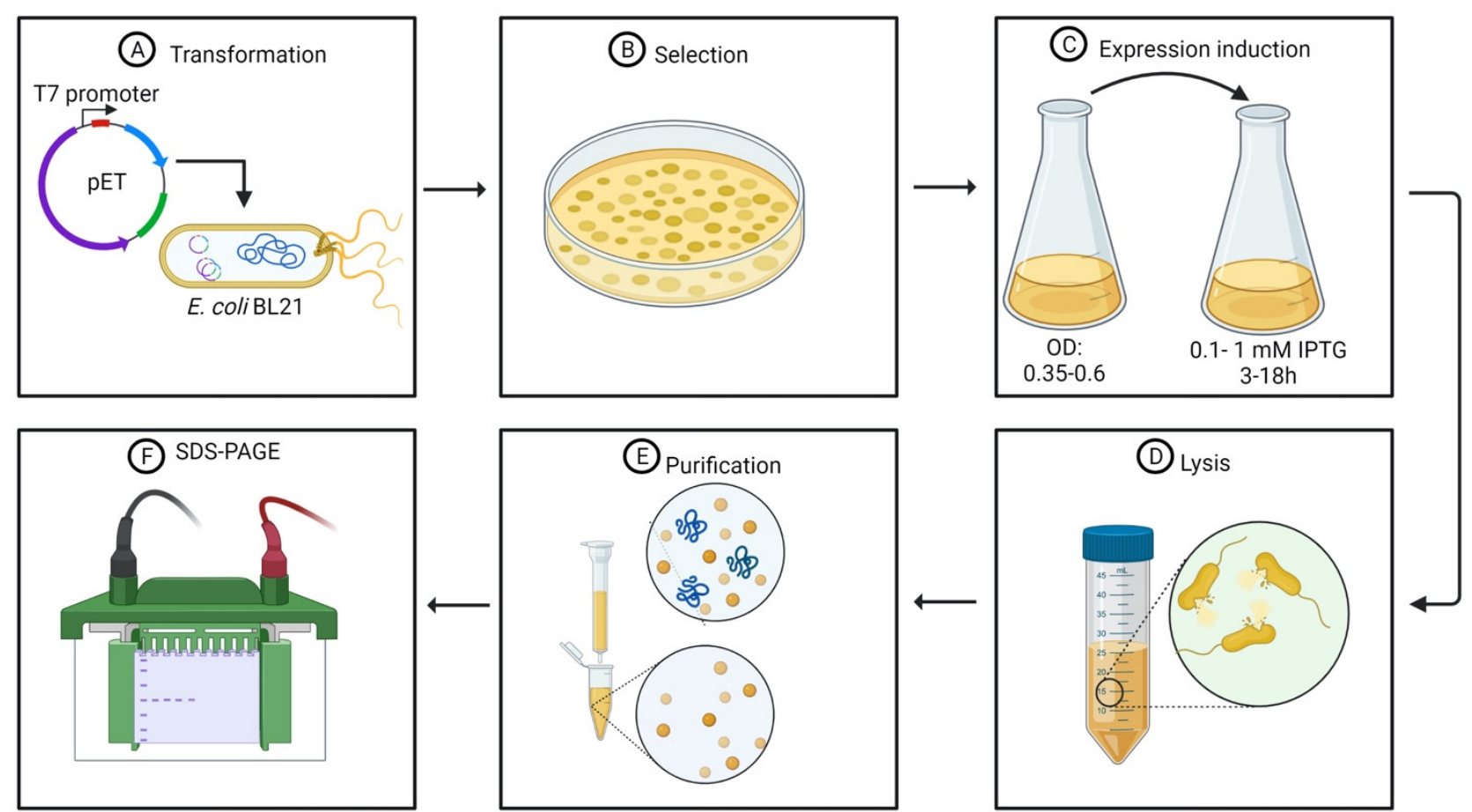

Figure 2. Standard protocol for endolysin heterologous expression: (A) bacterial transformation; (B) bacterial selection; (C) expression induction; (D) cell lysis; (E) endolysin purification; (F) SDS-PAGE.

Table 1. Heterologous expression vector, system, and induction of endolysins against Gram-negative bacteria.

\begin{tabular}{|c|c|c|c|c|}
\hline Endolysin & Vector & System & Induction & Reference \\
\hline LysAm24 & \multirow{3}{*}{$\mathrm{pET} 42 \mathrm{~b}$} & \multirow{3}{*}{ BL21(DE3) pLysS } & \multirow{3}{*}{$\begin{array}{l}\text { LB broth }\left(37^{\circ} \mathrm{C}, 240 \mathrm{rpm}\right) \text { to an OD600 of } 0.55-0.65 \\
\text { and } 1 \mathrm{mM} \mathrm{IPTG} \text { at } 37^{\circ} \mathrm{C} \text { for } 3 \mathrm{~h}\end{array}$} & \multirow{3}{*}{ [54] } \\
\hline LysECD7 & & & & \\
\hline LysSi3 & & & & \\
\hline BSP16Lys & pET28a & BL21(DE3) & $\begin{array}{l}\text { LB broth }\left(37^{\circ} \mathrm{C}\right) \text { to an OD600 of } 0.5 \text { and } 0.5 \mathrm{mM} \text { IPTG } \\
\text { at } 37^{\circ} \mathrm{C} \text { for } 3 \mathrm{~h}\end{array}$ & [55] \\
\hline LysAB54 & pET28a & BL21(DE3) & $\begin{array}{l}\text { LB broth }\left(37^{\circ} \mathrm{C}\right) \text { to an OD } 600 \text { of } 0.6 \text { and } 1.0 \mathrm{mM} \text { IPTG } \\
\text { at } 16^{\circ} \mathrm{C} \text { for } 16 \mathrm{~h}\end{array}$ & [49] \\
\hline ElyA1 & \multirow{2}{*}{ pET28a } & \multirow{2}{*}{ Rosetta (DE3) pLysS } & \multirow{2}{*}{$\begin{array}{c}\text { LB broth }\left(37^{\circ} \mathrm{C}, 180 \mathrm{rpm}\right) \text { and } 1 \mathrm{mM} \text { IPTG at } 30^{\circ} \mathrm{C} \\
\text { for } 5 \mathrm{~h}\end{array}$} & \multirow{2}{*}{ [56] } \\
\hline ElyA2 & & & & \\
\hline LysPA26 & pET28b & BL21(DE3) & LB broth $\left(37^{\circ} \mathrm{C}\right)$ and $1 \mathrm{mM} \mathrm{IPTG}$ at $25^{\circ} \mathrm{C}$ for $5 \mathrm{~h}$ & [24] \\
\hline LysSS & pET21 & BL21(DE3) & $\begin{array}{l}\text { LB broth }\left(37^{\circ} \mathrm{C}\right) \text { to an OD } 600 \text { of } 0.5 \text { and } 0.1 \mathrm{mM} \text { IPTG } \\
\text { at } 18^{\circ} \mathrm{C} \text { for } 16 \mathrm{~h}\end{array}$ & [47] \\
\hline LysSPN1S & pET15 & BL21(DE3) & LB broth to an OD600 of 0.6 and $1 \mathrm{mM}$ IPTG for $3 \mathrm{~h}$ & [51] \\
\hline LysSPN9CC & $\mathrm{pET} 29 \mathrm{~b}$ & BL21(DE3) & LB broth to an OD600 of 0.6 and $1 \mathrm{mM}$ IPTG for $4 \mathrm{~h}$ & {$[52]$} \\
\hline Lys68 & pET28a & BL21(DE3) & \multirow{2}{*}{$\begin{array}{c}\text { LB broth }\left(37^{\circ} \mathrm{C}, 120 \mathrm{rpm}\right) \text { to an OD600 of } 0.6 \text { and } 0.5 \\
\text { mM IPTG at } 16^{\circ} \mathrm{C} \text { for } 18 \mathrm{~h}\end{array}$} & [48] \\
\hline Abgp46 & pET15b & BL21(DE3) & & [31] \\
\hline Lysep3 & pET28a & BL21(DE3) & $\begin{array}{c}\text { LB broth }\left(37^{\circ} \mathrm{C}, 180 \mathrm{rpm}\right) \text { to an OD600 of } 0.35 \text { and } 0.1 \\
\text { mM IPTG at } 37^{\circ} \mathrm{C} \text { for } 3 \mathrm{~h}\end{array}$ & [53] \\
\hline
\end{tabular}

\section{Recombinant His-Tagged Endolysins Are Purified Using Affinity Chromatography}

The first step for protein purification consists of cell lysis (Figure 2D). After incubation and consequent protein synthesis, the E. coli cells are collected by centrifugation, generally under refrigeration temperatures, at angular speeds superior to $6000 \times g$ for at 
least $10 \mathrm{~min}[48,54]$. The harvested cells are then resuspended in a lysis buffer. The lysis buffer contains Tris $\mathrm{HCl}, \mathrm{NaCl}$ with [54,55] or without [51] ethylenediaminetetraacetic acid (EDTA). Some authors have also associated Tris $\mathrm{HCl}$ and $\mathrm{NaCl}$ with $\mathrm{ZnCl}_{2}$ to enhance protein solubility [47]. Mixtures of $\mathrm{NaH}_{2} \mathrm{PO}_{4}$ and $\mathrm{NaCl}$ are also used as a lysis buffer [31,48,52]. Phenylmethylsulfonyl fluoride (PMSF) and other protease inhibitor cocktails can be added to the lysis buffer to prevent endolysin hydrolysis by nonspecific proteases present in the culture media [55].

Cell disruption is achieved by the addition of lysozyme followed by sonication [54,55], chloroform followed by shaking [47] and some authors have also caused lysis in E. coli cells using sonication $[43,51,52,56]$. Freeze-thawing cycles help cell lysis by sonication $[31,48]$. Cell debris is then removed by centrifugation, generally under refrigeration temperature to prevent protein degradation, at angular speeds superior to $10,000 \times g$ for at least $30 \mathrm{~min}[31,48,55]$, and the supernatant is filtered through a $0.22 \mu \mathrm{m}$ pore size membrane $[54,55]$. The recombinant proteins present in the filtered supernatant are then subjected to purification.

The current state of the art concerning endolysin purification strategies lies in the use of polyhistidine tags, a standard procedure for general protein purification (Figure 2E). Histidine tags can be either added at the N-terminal $[31,48,50,51]$ or at the C-terminal $[47,52,54,55]$ region of the endolysin. Most of the endolysins evaluated are added to a 6-His fusion tag; however, 8- and 12-His tags have also been tested [55]. Several pET-type plasmids have an affinity tag composed of 6-His at the N-terminal region for further protein purification using metal-charged columns $[46,57]$. Recombinant proteins containing polyhistidine tags at the N-terminal region or comprising tags of more than six histidine residues must have their nucleotide sequence added on histidine codons $[46,58]$. The size and the position of the polyhistidine tag do not influence purification efficiency or wield. Nevertheless, polyhistidine tag size influences the antimicrobial activity of purified endolysins [55]. This influence will be discussed in Section 4.1 .

The purification of endolysins possessing polyhistidine tags is made by affinity chromatography using nickel-charged columns employing a linear gradient of imidazole eluted in a solution containing Tris- $\mathrm{HCl}$ buffer and $\mathrm{NaCl}[31,47,48,50-52,54,55]$. The polyhistidine tag interacts with the $\mathrm{Ni}^{2+}$ ion and, in the following step of elution, the imidazole ring, whose structure is similar to the side-chain of histidine residues, displaces the proteins during several passages of the elution buffer [59]. The following step consists of dialysis of the purified proteins against an elution buffer, such as PBS, to remove the imidazole excess [31,48]. Later, the purity of the proteins is assessed by SDS-PAGE (Figure 2F) [31,47,50,54-56] and the purified protein are stored at $-80{ }^{\circ} \mathrm{C}$ in buffers either containing Tris- $\mathrm{HCl}, \mathrm{NaCl}$, and glycerol [50,51] or sodium phosphate, $\mathrm{NaCl}$, and glycerol [52].

\section{Endolysins as Therapeutic Agents against Gram-Negative Bacteria}

Bacterial strains develop resistance to bacteriophages by mutations, receptor modification, passive adaptation, restriction modification, CRISPR-Cas, and pseudolysogeny [60]. However, there are no reports of bacteria developing resistance to endolysins [56]. A study performed by Briers et al. (2014) [61] evaluated the endolysin KZ144 fused with the antimicrobial peptide SMAP-29 and observed that the continuous exposure to the engineered endolysins did not lead to the development of antimicrobial resistance in $P$. aeruginosa. Similar results were found by other authors [62-65]. Resistance to antibiotics occurs because generally antibiotics act on inhibiting essential metabolic pathways of bacteria leading to cell death. However, bacteria find alternative pathways to overcome antimicrobial exposure [66]. Once endolysins act on such a conserved structure as the peptidoglycan, it is difficult for bacteria to evolve means of resistance to endolysins without damaging cell integrity $[67,68]$.

The term "enzybiotic" was attributed in 2001 to define the application of bacteriophagederived enzymes for treating bacterial infections [69]. In comparison to the use of bacterio- 
phages, the application of endolysins as antibacterial agents has several advantages [70]: (I) endolysins have broad-spectrum antimicrobial activity, which can also be a disadvantage by disturbing the microbiota; however, (II) antimicrobial potential can be modified by changing the endolysin concentration; (III) endolysins can act on both dormant and growing cells; (IV) no bacterial resistance to endolysins has been reported; (V) action against bacterial biofilms; (VI) lower degree of antibody neutralization; (VII) better-defined pharmacokinetics; and (VIII) versatility on combined application with organic acids, antibiotics, proteins, and other active molecules.

Table 2 summarizes some studies that have explored the application of recombinant endolysins against Gram-negative pathogens.

Table 2. Summary of research that evaluated the exogenous antimicrobial activity of endolysins against Gram-negative pathogens ${ }^{1}$.

\begin{tabular}{ll}
\hline Type of Study & \multicolumn{1}{c}{ Main Findings } \\
\hline Native endolysins & $\begin{array}{l}\text { Polyhistidine tags influence outer membrane permeation. } \\
\text { Transmembrane regions in the N-terminal region of endolysins comprising } \\
\text { signal-arrest-release domains could be responsible for outer membrane } \\
\text { permeation. } \\
\text { The mechanisms of outer membrane permeation by endolysins remain } \\
\text { inconclusive, but both in vitro and in vivo research revealed that some native } \\
\text { endolysins can inhibit Gram-negative bacteria. }\end{array}$ \\
\hline
\end{tabular}

Native endolysins combined with outer membrane permeabilizers

Organic acids improve the antimicrobial activity of endolysins or facilitate the permeation of endolysins.

Liposomes, silver nanoparticles, and polymyxins facilitate outer membrane permeation of endolysins.

Engineered endolysins

Hybrids of endolysins with outer membrane receptors, bacteriocins, and outer membrane-destabilizing peptides enhance endolysin diffusion.

${ }^{1}$ Check text for references.

\subsection{Some Native Endolysins Reach the Peptidoglycan Layer Per Se}

Antonova et al. (2019) [54] obtained a minimal active concentration of $0.5 \mu \mathrm{g} \cdot \mathrm{mL}^{-1}$ for LysAm24, encoded by the Acinetobacter phage AM24, and LysECD7, encoded by the Escherichia phage ECD7, and $0.5 \mu \mathrm{g} \cdot \mathrm{mL}^{-1}$ for LysSi3, encoded by the Enterobacteria phage UAB_Phi87, recombinant endolysins, reducing up to 3-log cycles of Acinetobacter baumannii counts. Endolysin concentrations superior to $5 \mu \mathrm{g} \cdot \mathrm{mL}^{-1}$ (LysAm24 and LysECD7) and $50 \mu \mathrm{g} \cdot \mathrm{mL}^{-1}$ (LysSi3) eliminated A. baumannii growth without the addition of outer membrane permeabilizers. The authors hypothesized that the cell permeation of recombinant endolysins was improved by the 8-His tag at the C-terminal region. The authors also observed that endolysins were more active when applied in the bacterial exponential growth phase than in the stationary phase.

In the following study, Antonova et al. (2020) [55] evaluated the polyhistidine tag hypothesis raised in their previous study. The author evaluated the antimicrobial activity of LysECD7 recombinant endolysin (native LysECD7, LysECD7-6his, LysECD7-8his, LysECD7-12his) at $1.0 \mu \mathrm{g} \cdot \mathrm{mL}^{-1}$ over a $\mathrm{pH}$ gradient. All His-tagged endolysins were less active compared to the native enzyme. The authors observed that the outer membrane permeation is achieved by other features other than the polyhistidine tags.

Lim et al. (2014) [52] observed a lytic activity of the SPN9CC endolysin, encoded by the Salmonella bacteriophage SPN9CC, against E. coli at an endolysin concentration of $300 \mu \mathrm{g} \cdot \mathrm{mL}^{-1}$ after $1 \mathrm{~h}$. The authors suggested that the presence of a transmembrane helix in the $\mathrm{N}$-terminal region of the endolysin comprising a signal-arrest-release (SAR) domain could be responsible for the outer membrane penetration. The study observed that the SAR domain plays a major role in the antibacterial activity; once SPN9CC endolysin deleted of some amino acids in the N-terminal region, it showed no lytic activity.

Guo et al. (2017) [24] observed that LysPA26 recombinant endolysin, predicted to belong to the lysozyme-like domain family and encoded by the Pseudomonas bacteriophage 
JD010, showed bactericidal activity against exponentially growing P. aeruginosa as a function of concentration, reaching a maximum activity at $500 \mu \mathrm{g} \cdot \mathrm{mL}^{-1}$ without outer membrane permeabilizers. The concentration of $500 \mu \mathrm{g} \cdot \mathrm{mL}^{-1}$ reduced $100 \%$ of the P. aeruginosa cells, compared to a reduction of $20 \%$ at a $50 \mu \mathrm{g} \cdot \mathrm{mL}^{-1}$. Additionally, P. aeruginosa biofilm was significantly reduced after the addition of LysPA26 up to $50 \mu \mathrm{g}$.

A study conducted by Kim et al. (2020) [47] showed that LysSS recombinant endolysin, belonging to the lyzozyme family and encoded by the Salmonella bacteriophage SS3e, had antibacterial activity against A.baumannii, E. coli, Klebsiella pneumoniae, P. aeruginosa, and Salmonella without the addition of outer permeabilizers. The minimum inhibitory concentration was inferior to $750 \mu \mathrm{g} \cdot \mathrm{mL}^{-1}$ and the minimum bactericidal concentration for A. baumannii was $250 \mu \mathrm{g} \cdot \mathrm{mL}^{-1}$ and $500 \mu \mathrm{g} \cdot \mathrm{mL}^{-1}$ for P. aeruginosa. LySS endolysin showed antimicrobial activity against Gram-positive pathogen S. aureus $\left(750 \mu \mathrm{g} \cdot \mathrm{mL}^{-1}\right)$; such activity against both Gram-positive and Gram-negative bacteria is unusual. The in vivo mice model with an intraperitoneally induced $A$. baumannii infection treated with $125 \mu \mathrm{g}$ of LysSS resulted in a $40 \%$ survival rate after 4 days of infection.

The mechanisms of outer membrane permeation of the endolysins evaluated by Guo et al. (2017) and Kim et al. (2020) remain unclear.

\subsection{Outer Membrane Permeabilizers Improve Native Endolysin Diffusion}

Although some endolysins act exogenously against Gram-negative bacteria in the absence of outer membrane permeabilizers, the antibacterial activity of endolysins is enhanced when combined with chemical permeabilizers [24,52,54]. Some studies mentioned in Section 4.1 observed better antibacterial activity combining purified endolysins with outer membrane permeabilizers. Antonova et al. (2019) [54] observed that the addition of EDTA improved the endolysin antibacterial activity in the stationary phage, inhibiting $P$. aeruginosa, $A$. baumannii, and K. pneumoniae.

Guo et al. (2017) [24] observed that 1 mM EDTA enhanced the LysPA26 antimicrobial activity and Lim et al. (2014) [52] observed that the tested Gram-negative bacteria (S. enterica, E. coli, P. aeruginosa, Pseudomonas putida, Shigella boydii, Shigella flexneri, Vibrio fischeri, and Vibrio vulnificus) were more susceptible to SPN9CC endolysin $\left(0.5 \mu \mathrm{g} \cdot \mathrm{mL}^{-1}\right)$ after an EDTA pretreatment.

Other studies, however, reported endolysins functioning only in the presence of outer membrane permeabilizers. Oliveira et al. (2014) [48] observed that in the presence of organic acids (0.5 mM EDTA, $2 \mathrm{mM}$ of citric acid, or $5 \mathrm{mM}$ of malic acid), antibacterial activity was observed for Lys68, encoded by the Salmonella phage phi68. Higher log reduction values were obtained using malic acid, acting against Salmonella Typhimurium, A. baumannii, P. aeruginosa, Pseudomonas fluorescens, Shigella sonnei, E. coli, Cronobacter sakazakii, Pantoea agglomerans, Enterobacter amnigenus, Proteus mirabilis, and Salmonella bongori. A similar study revealed that the pretreatment of $E$. coli with EDTA $(0.50 \mathrm{mM})$, citric acid $(0.36 \mathrm{mM})$, malic acid $(0.60 \mathrm{mM})$, lactic acid $(1.20 \mathrm{mM})$, benzoic acid $(1.20 \mathrm{mM})$, or acetic acid $(1.20 \mathrm{mM})$ enhances the antimicrobial activity of ABgp46 endolysin, encoded by the Acinetobacter phage vb_AbaP_CEB1 [31].

Lim et al. (2012) [51] treated E. coli cells with $0.03 \mu \mathrm{g} \cdot \mathrm{mL}^{-1}$ of SPN1S endolysin, encoded by the Salmonella bacteriophage SPN1S, and $5 \mathrm{mM}$ EDTA, resulting in an approximate 2-log reduction after $2 \mathrm{~h}$ and a 4-log reduction using $0.100 \mu \mathrm{g} \cdot \mathrm{mL}^{-1}$ endolysin and $10 \mathrm{mM}$ EDTA. All tested Gram-negative bacteria (E. coli, Salmonella Typhimurium, Salmonella Typhi, Salmonella Paratyphi, S. flexneri, P. aeruginosa, P. putida, C. sakazakii, and $V$. vulnificus) were lysed by SPN1S endolysin at $0.05 \mu \mathrm{g} \cdot \mathrm{mL}^{-1}$ after $10 \mathrm{~min}$, however, no activity was detected against Gram-positive bacteria.

Bai et al. (2019) [50] purified the BSP16Lys endolysin, encoded by the Salmonella bacteriophage BSP16, and observed antimicrobial activity against EDTA pretreated Salmonella Typhimurium and E. coli cells at a concentration of $0.15 \mu \mathrm{M}$. However, no activity was observed against EDTA non-treated cells. The absence of antimicrobial activity of BSP16Lys in the absence of EDTA was bypassed after endolysin encapsulation in liposomes. Encapsu- 
lated endolysins were evaluated against Salmonella Typhimurium and E. coli cells without an EDTA pretreatment and showed similar results to the free BSP16Lys applied in EDTA treated cells.

Blasco et al. (2020) [56] evaluated the combined effect of endolysins and the membranedestabilizing antibiotic colistin. The combination of the endolysin ElyA1, encoded by the Acinetobacter bacteriophage Ab105-1phi, with colistin reduced the minimal inhibitory concentration of colistin by up to $\frac{1}{4}$, resulting in a 2-log reduction in the counts of both $A$. baumannii and $P$. aeruginosa after $6 \mathrm{~h}$. The in vivo survival model of Galleria mellonellainfected larvae treated with colistin $\left(\frac{1}{4} \mathrm{MIC}\right)$ combined with ElyA1 endolysin $\left(25 \mu \mathrm{g} \cdot \mathrm{mL}^{-1}\right)$ was higher than that treated only with colistin $\left(\frac{1}{4} \mathrm{MIC}\right)$. In mice, superficial skin wounds infected with $A$. baumannii treated with colistin combined with $50 \mu \mathrm{g}$ and $350 \mu \mathrm{g}$ of ElyAl showed cell counts lower in the colistin combination treatments than in the buffer control.

Ciepluch et al. (2019) [71] combined bacteriophage lytic enzymes with dendritic silver nanoparticles (AgNPs), considered a potent outer membrane-disrupting agent. It was shown that dendritic AgNPs create a complex with lipopolysaccharides (LPSs) comprised in the outer membrane of Gram-negative bacteria and enhanced the antibacterial effect of the endolysins evaluated. A concentration of $20 \mu \mathrm{g} \cdot \mathrm{mL}^{-1}$ of dendritic AgNPs with endolysin $(5 \mu \mathrm{M})$ reduced up to $80 \%$ in the OD600 of the P. aeruginosa PAO1 model compared to the non-treated bacterial culture.

The use of outer membrane permeabilizers, such as EDTA [72] and antibiotics [73] leading to synergistic drug interactions, and liposomes [74] for assisted drug delivery have promising clinical impact. Further studies are still required to determine the proper outer membrane permeabilizers for further in vivo investigation.

\subsection{Protein Design Favors Endolysin Permeation through the Outer Membrane}

The limited application of endolysins against Gram-negative bacteria due to the low permeability of the outer membrane resulted in the development of engineered endolysins, including (I) innolysins; (II) lysocins; and (II) artilysins.

Innolysins combine the peptidoglycan disruption activity of native endolysins with phage receptor binding proteins, adhesion structural proteins that bind to surface receptors found in the outer membrane of Gram-negative bacteria, such as proteins, LPS, capsule components, pili, and flagella [75]. Nine of the twelve innolysins constructed by Zampara et al. (2020) [75] presented muralytic activity against P. aeruginosa PAO1, ranging from 126 to $771 \mu \mathrm{mol} \cdot \mathrm{min}^{-1} \cdot \mathrm{mL}^{-1}$. A study by Lukacik et al. (2012) [76] constructed an endolysin hybrid containing the T4 lysozyme attached to the FyuA-targeting domain found in pesticin. The endolysin hybrid could kill model E. coli cells expressing the FyuA gene and other species of bacteria encoding the FyuA gene, such as Yersinia pseudotuberculosis and Y. pestis. Additionally, Briers et al. (2014) [77] developed the concept of artilysins based on the construction of endolysin hybrids containing LPS-destabilizing peptides (cationic, hydrophobic, or amphipathic domains). Artilysins could kill multidrug-resistant bacteria such as P. aeruginosa, A. baumannii, E. coli, and Salmonella Typhimurium in vitro and in vivo (Caenorhabditis elegans and keratinocytes).

\section{Thermally Resistant Endolysins Are Promising Candidates for Drug Development}

Thermally resistant endolysins are important in terms of clinical applications; once thermostable proteins are more easily handled and tend to keep their activity for longer periods. Mikoulinskaia et al. (2018) [78] identified, cloned, and performed the biochemical characterization of two novel thermally resistant endolysins: RB43 endolysin retained $81 \%$ of its activity after a $10 \mathrm{~min}$ at $90{ }^{\circ} \mathrm{C}$ and $\mathrm{RB} 49$ endolysin that retained $27 \%$ of its activity after the same treatment. Plotka et al. (2014) [42], on the other hand, evaluated the $\mathrm{Ph} 2119$ endolysin, whose activity remained around $87 \%$ after $6 \mathrm{~h}$ at $95{ }^{\circ} \mathrm{C}$ and optimum temperature ranges from $50{ }^{\circ} \mathrm{C}$ to $78{ }^{\circ} \mathrm{C}$. The endolysin showed lytic activity toward Grampositive thermophiles (Thermus scotoductus, Thermus thermophilus, and Thermus flavus), and Gram-negative bacteria (E. coli, S. marcescens, P. fluorescens, and S. enterica). Plotka 
et al. (2015) [79] obtained similar results for Ts2631 endolysin, whose activity was retained at $64.8 \%$ after $2 \mathrm{~h}$ at $95{ }^{\circ} \mathrm{C}$ and with antibacterial spectrum including Gram-positive thermophiles and Gram-negative bacteria. Plotka et al. (2019) [80] completed the study with Ts2631 endolysin and evaluated the combined effect of the enzyme with EDTA and organic acids. The results revealed at least a 2.9-log reduction in the counts of carbapenemresistant $A$. baumannii and 6-log reductions in the counts of multidrug-resistant Citrobacter braakii. Finally, Wang et al. (2020) [81] evaluated MMPphg thermally stable endolysin (80\% of its activity retained after $30 \mathrm{~min}$ at $65^{\circ} \mathrm{C}$ ) and observed antimicrobial activity against both Gram-negative and Gram-positive antibiotic-resistant strains, such as E. coli O157:H7, S. aureus, and K. pneumonia.

\section{Bacteriophage Depolymerases Might Act Synergistically with Endolysins}

Depolymerases are phage-derived enzymes that degrade capsular polysaccharides, extracellular polymeric substances, and the O-antigen, offering a promising tool for controlling multidrug-resistant bacteria [82]. Wang et al. (2020) [83] evaluated the action of the purified depolymerase Dp49 $\left(250 \mu \mathrm{g} \cdot \mathrm{mL}^{-1}\right)$, encoded by the Acinetobacter phage vB_AbaM_IME285, combined with activated serum and observed that the bacterial counts decreased, reaching up to a 4-log reduction. All mice evaluated infected with the lethal dose of A. baumannii ( $200 \mu \mathrm{L}$ at $\left.6 \times 10^{7} \mathrm{CFU}\right)$ died in the first $24 \mathrm{~h}$. However, all mice treated with Dp49 (50 $\mu \mathrm{g}$ ) survived. Similar results were found by Pan et al. (2015) [84] evaluating the activity of depolymerases against carbapenem-resistant K. pneumoniae strains. Studies accounting for the combined effect of depolymerases and phage endolysins on Gram-negative bacteria are still missing.

\section{Metagenomics in the Discovery of New Endolysins}

Metagenomics could be used as a strategy to screen potential endolysins for potential in vitro and in vivo studies. Fernández-Ruiz et al. (2018) [85] used a bioinformatics approach to analyze the genomes of approximately 200 thousand uncultured bacteriophages. The authors discovered 2628 putative endolysins, including endolysins comprising novel domain architectures. Currently, there is a growing body of research evaluating the distribution of unculturable viral genomes across the globe. Metagenomics will generate an abundance of genetic information from uncultured bacteriophages, and this massive data will potentially expand the knowledge on endolysin diversity and evolution. Therefore, further studies require the determination of biodiversity-shaping factors that affect the bacteriophage-endolysin-bacteria ecology.

\section{Limitations of Endolysin Therapy}

Despite promising results and high therapeutic potential, there are four major limitations on endolysin-based treatment: (I) pharmacokinetics and immunomodulatory aspects; (II) drug delivery methods variety; (III) specificity for general treatments; and (IV) regulatory issues.

First, defining endolysin pharmacokinetics and immunomodulatory properties currently comprises a clinical gap. These characteristics were explored in Section 4. Multimodular proteins, proteins with different catalytic and cell-binding domains, lead to considerable variations in antimicrobial activity and will probably affect formulation design and pharmacokinetics [86]. These characteristics point to the idea that endolysin systems need to be carefully designed for each endolysin.

The majority of endolysin-based products have topical uses, which are ideal for skin and wound infections, but not suitable for many other parts of the body. Due to the protein character of endolysins, the oral administration of endolysins is difficult given that drugs must transit the entirety of the gastrointestinal tract [87]. Considering other administration routes, endolysins can trigger the immune system [88]. This constraint highlights the need for investigation to protect endolysins from the immune system. 
In addition, Murray et al. (2021) [89] highlighted that endolysins generally have more specificity than common antibiotics. Most of the studies on endolysins are conducted on specific infections. In contrast, many antibiotics are prescribed and used by people with simple illnesses. The main challenge is to determine whether such personalized treatment is an economically viable alternative.

Concerning regulatory issues, most of the studies on endolysins-based treatments are based on recombinant DNA technology and heterologous expression. This method has specific requirements and guidelines that make endolysin production and use in human therapy difficult [89] and the legal framework for endolysin applications is currently unstandardized [90].

Considering these four limitations, especially the individuality of endolysin treatments and scale-up efforts, the cost of the development of endolysin-based drugs is currently higher than that of conventional antibiotics [86]. Despite these limitations, endolysinsbased treatments are expected to enter clinical trials in a near future.

\section{Conclusions}

The antimicrobial resistance crisis has boosted endolysin research in the past few years, and endolysins show great potential to replace or supplement antibiotic treatments. There is no complexity in terms of the expression vector and expression system in the heterologous expression of endolysins, and purification strategies for recombinant endolysins are well established. Nevertheless, extensive knowledge on both efficacity and size of the His tag is still required to determine the most effective antibacterial effect of endolysins against Gram-negative bacteria. Recombinant endolysins act on the Gram-negative cells either in the presence or in the absence of outer membrane permeabilizers. However, there are still many challenges to be addressed before the clinical use of endolysins, including the administration mechanisms of endolysin-based drugs. As previously addressed by Love et al. (2018) [91], the current status of endolysin-based treatments against Gram-negative pathogens highlights the study of scale-up production and the definition of regulations in several fields of application.

Author Contributions: Conceptualization, M.T.P.G. and M.B.; writing—original draft preparation, M.T.P.G. and G.P.J.; writing—review and editing, M.B.; supervision, M.B.; project administration, M.B.; All authors have read and agreed to the published version of the manuscript.

Funding: This research was funded by Fundação de Amparo à Pesquisa do Estado de São Paulo, grant number 2020/01535-9. M.T.P.G. was supported by Conselho Nacional de Desenvolvimento Científico e Tecnológico, grant number 130553/2020-4 and Fundação de Amparo à Pesquisa do Estado de São Paulo, grant number 2020/01535-9. G.P.J. is supported by Departamento Administrativo de Ciencia, Tecnologia e Innovacion, grant number 2016/772. M.B. was supported by Conselho Nacional de Desenvolvimento Científico e Tecnológico, grant number: 309380/2019-7, and M.B. Fundação de Amparo à Pesquisa do Estado de São Paulo, grant number 2017/10051-2.

Institutional Review Board Statement: Not applicable.

Informed Consent Statement: Not applicable.

Data Availability Statement: Not applicable.

Acknowledgments: Figures were created with BioRender.com (accessed on 21 July 2021).

Conflicts of Interest: The authors declare no conflict of interest. 


\section{References}

1. Aslam, B.; Wang, W.; Arshad, M.I.; Khurshid, M.; Muzammil, S.; Rasool, M.H.; Nisar, M.A.; Alvi, R.F.; Aslam, M.A.; Qamar, M.U.; et al. Antibiotic resistance: A rundown of a global crisis. Infect. Drug Resist. 2018, 11, 1645-1658. [CrossRef]

2. Ventola, C.L. The Antibiotic Resistance Crisis: Part 1: Causes and threats. Pharm. Ther. 2015, 40, $277-283$.

3. Boggione, D.M.; Batalha, L.S.; Gontijo, M.T.; Lopez, M.E.; Teixeira, A.V.; Santos, I.J.; Mendonça, R.C. Evaluation of microencapsulation of the UFV-AREG1 bacteriophage in alginate-Ca microcapsules using microfluidic devices. Colloids Surfaces B Biointerfaces 2017, 158, 182-189. [CrossRef] [PubMed]

4. Gould, K. Antibiotics: From prehistory to the present day. J. Antimicrob. Chemother. 2016, 71, 572-575. [CrossRef]

5. Pepper, J.W. The evolution of bacterial social life: From the ivory tower to the front lines of public health. Evol. Med. Public Health 2014, 2014, 65-68. [CrossRef]

6. Zgurskaya, H.I.; López, C.A.; Gnanakaran, S. Permeability Barrier of Gram-Negative Cell Envelopes and Approaches to Bypass It. ACS Infect. Dis. 2015, 1, 512-522. [CrossRef]

7. Bello, A.; Dingle, T. What's That Resistance Mechanism? Understanding Genetic Determinants of Gram-Negative Bacterial Resistance. Clin. Microbiol. Newsl. 2018, 40, 165-174. [CrossRef]

8. Eichenberger, E.; Thaden, J.T. Epidemiology and Mechanisms of Resistance of Extensively Drug Resistant Gram-Negative Bacteria. Antibiotics 2019, 8, 37. [CrossRef]

9. Breijyeh, Z.; Jubeh, B.; Karaman, R. Resistance of Gram-Negative Bacteria to Current Antibacterial Agents and Approaches to Resolve It. Molecules 2020, 25, 1340. [CrossRef]

10. Étienne, R.; Woerther, P.-L.; Barbier, F. Mechanisms of antimicrobial resistance in Gram-negative bacilli. Ann. Intensiv. Care 2015, 5, 1-15. [CrossRef]

11. Exner, M.; Bhattacharya, S.; Christiansen, B.; Gebel, J.; Goroncy-Bermes, P.; Hartemann, P.; Heeg, P.; Ilschner, C.; Kramer, A.; Larson, E.; et al. Antibiotic resistance: What is so special about multidrug-resistant Gram-negative bacteria? GMS Hyg. Infect. Control 2017, 12. [CrossRef]

12. Twort, F. An Investigation on the Nature of Ultra-Microscopic Viruses. Lancet 1915, 186, 1241-1243. [CrossRef]

13. D'Herelle, F. Bacteriophage as a Treatment in Acute Medical and Surgical Infections. Bull. N. Y. Acad. Med. 1931, 7, 329-348.

14. Jacob, F.; Monod, J. Genetic regulatory mechanisms in the synthesis of proteins. J. Mol. Biol. 1961, 3, 318-356. [CrossRef]

15. Ishino, Y.; Krupovic, M.; Forterre, P. History of CRISPR-Cas from Encounter with a Mysterious Repeated Sequence to Genome Editing Technology. J. Bacteriol. 2018, 200, e00580-17. [CrossRef]

16. Lopez, M.E.S.; Batalha, L.S.; Vidigal, P.M.P.; Albino, L.A.A.; Boggione, D.M.G.; Gontijo, M.T.P.; Bazzolli, D.M.S.; Mendonca, R.C.S. Genome Sequence of the Enterohemorrhagic Escherichia coli Bacteriophage UFV-AREG1. Genome Announc. 2016, 4, e00412-16. [CrossRef]

17. Gontijo, M.T.; Batalha, L.S.; Lopez, M.E.; Albino, L.A. Bacteriophage Genome Sequencing: A New Alternative to Understand Biochemical Interactions between Prokaryotic Cells and Phages. J. Microb. Biochem. Technol. 2017, 9, 169-173. [CrossRef]

18. Lopez, M.; Gontijo, M.; Batalha, L.; Mendonca, R. Bio-Sanitization Using Specific Bacteriophages to Control Escherichia coli O157:H7 in Cherry Tomatoes. Adv. J. Food Sci. Technol. 2018, 16, 92-101. [CrossRef]

19. Batalha, L.S.; Gontijo, M.T.P.; Teixeira, A.V.N.D.C.; Boggione, D.M.G.; Lopez, M.E.S.; Eller, M.R.; Mendonça, R.C.S. Encapsulation in alginate-polymers improves stability and allows controlled release of the UFV-AREG1 bacteriophage. Food Res. Int. 2021, 139, 109947. [CrossRef]

20. Young, R.; Wang, I.-N.; Roof, W.D. Phages will out: Strategies of host cell lysis. Trends Microbiol. 2000, 8, 120-128. [CrossRef]

21. Matamp, N.; Bhat, S.G. Phage Endolysins as Potential Antimicrobials against Multidrug Resistant Vibrio alginolyticus and Vibrio parahaemolyticus: Current Status of Research and Challenges Ahead. Microorganisms 2019, 7, 84. [CrossRef]

22. Schmelcher, M.; Donovan, D.M.; Loessner, M.J. Bacteriophage endolysins as novel antimicrobials. Future Microbiol. 2012, 7, 1147-1171. [CrossRef]

23. Young, R. Phage lysis: Three steps, three choices, one outcome. J. Microbiol. 2014, 52, 243-258. [CrossRef]

24. Guo, M.; Feng, C.; Ren, J.; Zhuang, X.; Zhang, Y.; Zhu, Y.; Dong, K.; He, P.; Guo, X.-K.; Qin, J. A Novel Antimicrobial Endolysin, LysPA26, against Pseudomonas aeruginosa. Front. Microbiol. 2017, 8, 293. [CrossRef]

25. Saier, M.H.; Reddy, B.L. Holins in Bacteria, Eukaryotes, and Archaea: Multifunctional Xenologues with Potential Biotechnological and Biomedical Applications. J. Bacteriol. 2015, 197, 7-17. [CrossRef] [PubMed]

26. Young, R. Phage lysis: Do we have the hole story yet? Curr. Opin. Microbiol. 2013, 16, 790-797. [CrossRef]

27. Berry, J.D.; Rajaure, M.; Young, R. Spanin function requires subunit homodimerization through intermolecular disulfide bonds. Mol. Microbiol. 2013, 88, 35-47. [CrossRef]

28. Gontijo, M.T.P.; Vidigal, P.M.P.; Lopez, M.E.S.; Brocchi, M. Bacteriophages that infect Gram-negative bacteria as source of signal-arrest-release motif lysins. Res. Microbiol. 2021, 172, 103794. [CrossRef]

29. Ghose, C.; Euler, C.W. Gram-Negative Bacterial Lysins. Antibiotics 2020, 9, 74. [CrossRef]

30. Love, M.J.; Abeysekera, G.S.; Muscroft-Taylor, A.C.; Billington, C.; Dobson, R.C. On the catalytic mechanism of bacteriophage endolysins: Opportunities for engineering. Biochim. Biophys. Acta (BBA) Proteins Proteom. 2020, 1868, 140302. [CrossRef]

31. Oliveira, H.; Boas, D.V.; Emesnage, S.; Kluskens, L.D.; Lavigne, R.; Sillankorva, S.; Esecundo, F.; Eazeredo, J. Structural and Enzymatic Characterization of ABgp46, a Novel Phage Endolysin with Broad Anti-Gram-Negative Bacterial Activity. Front. Microbiol. 2016, 7, 208. [CrossRef] 
32. Altamirano, F.L.G.; Barr, J.J. Phage Therapy in the Postantibiotic Era. Clin. Microbiol. Rev. 2019, 32. [CrossRef]

33. Brives, C.; Pourraz, J. Phage therapy as a potential solution in the fight against AMR: Obstacles and possible futures. Palgrave Commun. 2020, 6, 1-11. [CrossRef]

34. Kortright, K.E.; Chan, B.K.; Koff, J.L.; Turner, P.E. Phage Therapy: A Renewed Approach to Combat Antibiotic-Resistant Bacteria. Cell Host Microbe 2019, 25, 219-232. [CrossRef] [PubMed]

35. Principi, N.; Silvestri, E.; Esposito, S. Advantages and limitations of bacteriophages for the treatment of bacterial infections. Front. Pharmacol. 2019, 10, 513. [CrossRef] [PubMed]

36. Kaur, J.; Kumar, A.; Kaur, J. Strategies for optimization of heterologous protein expression in E. coli: Roadblocks and reinforcements. Int. J. Biol. Macromol. 2018, 106, 803-822. [CrossRef]

37. Rosano, G.L.; Ceccarelli, E.A. Recombinant protein expression in Escherichia coli: Advances and challenges. Front. Microbiol. 2014, 5, 172. [CrossRef] [PubMed]

38. Nieuwkoop, T.; Claassens, N.J.; Van Der Oost, J. Improved protein production and codon optimization analyses in Escherichia coli by bicistronic design. Microb. Biotechnol. 2018, 12, 173-179. [CrossRef]

39. Parret, A.H.; Besir, H.; Meijers, R. Critical reflections on synthetic gene design for recombinant protein expression. Curr. Opin. Struct. Biol. 2016, 38, 155-162. [CrossRef] [PubMed]

40. Gopal, G.J.; Kumar, A. Strategies for the Production of Recombinant Protein in Escherichia coli. Protein J. 2013, 32, 419-425. [CrossRef]

41. Jia, B.; Jeon, C.O. High-throughput recombinant protein expression in Escherichia coli: Current status and future perspectives. Open Biol. 2016, 6, 6. [CrossRef]

42. Plotka, M.; Kaczorowska, A.-K.; Stefanska, A.; Morzywolek, A.; Fridjonsson, O.H.; Dunin-Horkawicz, S.; Kozlowski, L.; Hreggvidsson, G.O.; Kristjansson, J.K.; Dabrowski, S.; et al. Novel Highly Thermostable Endolysin from Thermus scotoductus MAT2119 Bacteriophage Ph2119 with Amino Acid Sequence Similarity to Eukaryotic Peptidoglycan Recognition Proteins. Appl. Environ. Microbiol. 2013, 80, 886-895. [CrossRef]

43. Bailly-Bechet, M.; Danchin, A.; Iqbal, M.; Marsili, M.; Vergassola, M. Codon Usage Domains over Bacterial Chromosomes. PLoS Comput. Biol. 2006, 2, e37. [CrossRef]

44. Chithambaram, S.; Prabhakaran, R.; Xia, X. The effect of mutation and selection on codon adaptation in Escherichia coli bacteriophage. Genetics 2014, 197, 301-315. [CrossRef]

45. Sharp, P.M. Codon Usage Bias. In Encyclopedia of Genetics; Brenner, S., Miller, J.H., Eds.; Academic Press: Cambridge, MA, USA, 2001; pp. 402-406, ISBN 978-0-12-227080-2.

46. Shilling, P.J.; Mirzadeh, K.; Cumming, A.J.; Widesheim, M.; Köck, Z.; Daley, D.O. Improved designs for pET expression plasmids increase protein production yield in Escherichia coli. Commun. Biol. 2020, 3, 1-8. [CrossRef]

47. Kim, S.; Lee, D.-W.; Jin, J.-S.; Kim, J. Antimicrobial activity of LysSS, a novel phage endolysin, against Acinetobacter baumannii and Pseudomonas aeruginosa. J. Glob. Antimicrob. Resist. 2020, 22, 32-39. [CrossRef]

48. Oliveira, H.; Thiagarajan, V.; Walmagh, M.; Sillankorva, S.; Lavigne, R.; Neves-Petersen, M.T.; Kluskens, L.; Azeredo, J. A Thermostable Salmonella Phage Endolysin, Lys68, with Broad Bactericidal Properties against Gram-Negative Pathogens in Presence of Weak Acids. PLoS ONE 2014, 9, e108376. [CrossRef] [PubMed]

49. Khan, F.M.; Gondil, V.S.; Li, C.; Jiang, M.; Li, J.; Yu, J.; Wei, H.; Yang, H. A Novel Acinetobacter baumannii Bacteriophage Endolysin LysAB54 With High Antibacterial Activity Against Multiple Gram-Negative Microbes. Front. Cell. Infect. Microbiol. $2021,11$. [CrossRef] [PubMed]

50. Bai, J.; Yang, E.; Chang, P.-S.; Ryu, S. Preparation and characterization of endolysin-containing liposomes and evaluation of their antimicrobial activities against gram-negative bacteria. Enzym. Microb. Technol. 2019, 128, 40-48. [CrossRef] [PubMed]

51. Lim, J.-A.; Shin, H.; Kang, D.-H.; Ryu, S. Characterization of endolysin from a Salmonella Typhimurium-infecting bacteriophage SPN1S. Res. Microbiol. 2012, 163, 233-241. [CrossRef]

52. Lim, J.-A.; Shin, H.; Heu, S.; Ryu, S. Exogenous Lytic Activity of SPN9CC Endolysin Against Gram-Negative Bacteria. J. Microbiol. Biotechnol. 2014, 24, 803-811. [CrossRef]

53. Yan, G.; Yang, R.; Fan, K.; Dong, H.; Gao, C.; Wang, S.; Yu, L.; Cheng, Z.; Lei, L. External lysis of Escherichia coli by a bacteriophage endolysin modified with hydrophobic amino acids. AMB Express 2019, 9, 1-7. [CrossRef] [PubMed]

54. Antonova, N.P.; Vasina, D.V.; Lendel, A.M.; Usachev, E.V.; Makarov, V.V.; Gintsburg, A.L.; Tkachuk, A.P.; Gushchin, V.A. Broad Bactericidal Activity of the Myoviridae Bacteriophage Lysins LysAm24, LysECD7, and LysSi3 against Gram-Negative ESKAPE Pathogens. Viruses 2019, 11, 284. [CrossRef] [PubMed]

55. Antonova, N.P.; Vasina, D.V.; Rubalsky, E.O.; Fursov, M.V.; Savinova, A.S.; Grigoriev, I.V.; Usachev, E.V.; Shevlyagina, N.V.; Zhukhovitsky, V.G.; Balabanyan, V.U.; et al. Modulation of Endolysin LysECD7 Bactericidal Activity by Different Peptide Tag Fusion. Biomolecules 2020, 10, 440. [CrossRef] [PubMed]

56. Blasco, L.; Ambroa, A.; Trastoy, R.; Bleriot, I.; Moscoso, M.; Fernandez-Garcia, L.; Perez-Nadales, E.; Fernández-Cuenca, F.; Torre-Cisneros, J.; Oteo-Iglesias, J.; et al. In vitro and in vivo efficacy of combinations of colistin and different endolysins against clinical strains of multi-drug resistant pathogens. Sci. Rep. 2020, 10, 1-12. [CrossRef]

57. Ramos, C.; Abreu, P.; Nascimento, A.; Ho, P. A high-copy T7 Escherichia coli expression vector for the production of recombinant proteins with a minimal N-terminal His-tagged fusion peptide. Braz. J. Med Biol. Res. 2004, 37, 1103-1109. [CrossRef] [PubMed] 
58. Yang, P.-C.; Liu, Z.-Q. Construction of pET-32 $\alpha(+)$ vector for protein expression and purification. N. Am. J. Med. Sci. 2012, 4, 651-655. [CrossRef]

59. Bornhorst, J.A.; Falke, J.J. Purification of proteins using polyhistidine affinity tags. Methods Enzymol. 2000, 326, 245-254. [CrossRef]

60. Mondal, S.I.; Draper, L.A.; Ross, R.P.; Hill, C. Bacteriophage endolysins as a potential weapon to combat Clostridioides difficile infection. Gut Microbes 2020, 12, 1813533. [CrossRef] [PubMed]

61. Briers, Y.; Walmagh, M.; Grymonprez, B.; Biebl, M.; Pirnay, J.-P.; Defraine, V.; Michiels, J.; Cenens, W.; Aertsen, A.; Miller, S.; et al. Art-175 Is a Highly Efficient Antibacterial against Multidrug-Resistant Strains and Persisters of Pseudomonas aeruginosa. Antimicrob. Agents Chemother. 2014, 58, 3774-3784. [CrossRef] [PubMed]

62. Gutiérrez, D.; Fernández, L.; Rodríguez, A.; García, P. Are Phage Lytic Proteins the Secret Weapon to Kill Staphylococcus aureus? mBio 2018, 9, e01923-17. [CrossRef]

63. Loeffler, J.M.; Nelson, D.; Fischetti, V.A. Rapid Killing of Streptococcus pneumoniae with a Bacteriophage Cell Wall Hydrolase. Science 2001, 294, 2170-2172. [CrossRef]

64. Gilmer, D.B.; Schmitz, J.E.; Euler, C.W.; Fischetti, V.A. Novel Bacteriophage Lysin with Broad Lytic Activity Protects against Mixed Infection by Streptococcus pyogenes and Methicillin-Resistant Staphylococcus aureus. Antimicrob. Agents Chemother. 2013, 57, 2743-2750. [CrossRef]

65. Pastagia, M.; Euler, C.; Chahales, P.; Fuentes-Duculan, J.; Krueger, J.G.; Fischetti, V.A. A Novel Chimeric Lysin Shows Superiority to Mupirocin for Skin Decolonization of Methicillin-Resistant and -Sensitive Staphylococcus aureus Strains. Antimicrob. Agents Chemother. 2010, 55, 738-744. [CrossRef]

66. Gerstmans, H.; Rodriguez-Rubio, L.; Lavigne, R.; Briers, Y. From endolysins to Artilysin ${ }^{\circledR}$ s: Novel enzyme-based approaches to kill drug-resistant bacteria. Biochem. Soc. Trans. 2016, 44, 123-128. [CrossRef] [PubMed]

67. Fischetti, V.A. Bacteriophage endolysins: A novel anti-infective to control Gram-positive pathogens. Int. J. Med. Microbiol. 2010, 300, 357-362. [CrossRef] [PubMed]

68. Fischetti, V.A. Using phage Lytic Enzymes to Control Pathogenic Bacteria. BMC Oral Health 2006, 6, S16. [CrossRef] [PubMed]

69. Nelson, D.; Loomis, L.; Fischetti, V.A. Prevention and elimination of upper respiratory colonization of mice by group A streptococci by using a bacteriophage lytic enzyme. Proc. Natl. Acad. Sci. USA 2001, 98, 4107-4112. [CrossRef] [PubMed]

70. Gondil, V.S.; Harjai, K.; Chhibber, S. Endolysins as emerging alternative therapeutic agents to counter drug-resistant infections. Int. J. Antimicrob. Agents 2020, 55, 105844. [CrossRef] [PubMed]

71. Ciepluch, K.; Skrzyniarz, K.; Barrios-Gumiel, A.; Quintana, S.; Sánchez-Nieves, J.; De La Mata, F.J.; Maciejewska, B.; Drulis-Kawa, Z.; Arabski, M. Dendronized Silver Nanoparticles as Bacterial Membrane Permeabilizers and Their Interactions with P. aeruginosa Lipopolysaccharides, Lysozymes, and Phage-Derived Endolysins. Front. Microbiol. 2019, 10, 2771. [CrossRef] [PubMed]

72. Finnegan, S.; Percival, S. EDTA: An Antimicrobial and Antibiofilm Agent for Use in Wound Care. Adv. Wound Care 2015, 4, 415-421. [CrossRef]

73. Bollenbach, T. Antimicrobial interactions: Mechanisms and implications for drug discovery and resistance evolution. Curr. Opin. Microbiol. 2015, 27, 1-9. [CrossRef]

74. Sercombe, L.; Veerati, T.; Moheimani, F.; Wu, S.; Sood, A.K.; Hua, S. Advances and Challenges of Liposome Assisted Drug Delivery. Front. Pharmacol. 2015, 6, 286. [CrossRef] [PubMed]

75. Zampara, A.; Sørensen, M.C.H.; Grimon, D.; Antenucci, F.; Vitt, A.R.; Bortolaia, V.; Briers, Y.; Brøndsted, L. Exploiting phage receptor binding proteins to enable endolysins to kill Gram-negative bacteria. Sci. Rep. 2020, 10, 1-12. [CrossRef] [PubMed]

76. Lukacik, P.; Barnard, T.J.; Keller, P.W.; Chaturvedi, K.S.; Seddiki, N.; Fairman, J.W.; Noinaj, N.; Kirby, T.L.; Henderson, J.P.; Steven, A.C.; et al. Structural engineering of a phage lysin that targets Gram-negative pathogens. Proc. Natl. Acad. Sci. USA 2012, 109, 9857-9862. [CrossRef]

77. Briers, Y.; Walmagh, M.; Van Puyenbroeck, V.; Cornelissen, A.; Cenens, W.; Aertsen, A.; Oliveira, H.; Azeredo, J.; Verween, G.; Pirnay, J.-P.; et al. Engineered Endolysin-Based "Artilysins" To Combat Multidrug-Resistant Gram-Negative Pathogens. mBio 2014, 5, e01379-14. [CrossRef]

78. Mikoulinskaia, G.V.; Chernyshov, S.V.; Shavrina, M.S.; Molochkov, N.V.; Lysanskaya, V.Y.; Zimin, A.A. Two novel thermally resistant endolysins encoded by pseudo T-even bacteriophages RB43 and RB49. J. Gen. Virol. 2018, 99, 402-415. [CrossRef] [PubMed]

79. Plotka, M.; Kaczorowska, A.-K.; Morzywolek, A.; Makowska, J.; Kozlowski, L.; Thorisdottir, A.; Skírnisdottir, S.; Hjörleifsdottir, S.; Fridjonsson, O.H.; Hreggvidsson, G.O.; et al. Biochemical Characterization and Validation of a Catalytic Site of a Highly Thermostable Ts2631 Endolysin from the Thermus scotoductus Phage vB_Tsc2631. PLoS ONE 2015, 10, e0137374. [CrossRef]

80. Plotka, M.; Kapusta, M.; Dorawa, S.; Kaczorowska, A.-K.; Kaczorowski, T. Ts2631 Endolysin from the Extremophilic Thermus scotoductus Bacteriophage vB_Tsc2631 as an Antimicrobial Agent against Gram-Negative Multidrug-Resistant Bacteria. Viruses 2019, 11, 657. [CrossRef]

81. Wang, F.; Xiong, Y.; Xiao, Y.; Han, J.; Deng, X.; Lin, L. MMPphg from the thermophilic Meiothermus bacteriophage MMP17 as a potential antimicrobial agent against both Gram-negative and Gram-positive bacteria. Virol. J. 2020, 17, 1-10. [CrossRef]

82. Knecht, L.E.; Veljkovic, M.; Fieseler, L. Diversity and Function of Phage Encoded Depolymerases. Front. Microbiol. 2020, 10, 2949. [CrossRef] [PubMed] 
83. Wang, C.; Li, P.; Zhu, Y.; Huang, Y.; Gao, M.; Yuan, X.; Niu, W.; Liu, H.; Fan, H.; Qin, Y.; et al. Identification of a Novel Acinetobacter baumannii Phage-Derived Depolymerase and Its Therapeutic Application in Mice. Front. Microbiol. 2020, 11, 1407. [CrossRef] [PubMed]

84. Pan, Y.-J.; Lin, T.-L.; Lin, Y.-T.; Su, P.-A.; Chen, C.-T.; Hsieh, P.-F.; Hsu, C.-R.; Chen, C.-C.; Hsieh, Y.-C.; Wang, J.-T. Identification of Capsular Types in Carbapenem-Resistant Klebsiella pneumoniae Strains bywzcSequencing and Implications for Capsule Depolymerase Treatment. Antimicrob. Agents Chemother. 2015, 59, 1038-1047. [CrossRef] [PubMed]

85. Fernández-Ruiz, I.; Coutinho, F.H.; Rodriguez-Valera, F. Thousands of Novel Endolysins Discovered in Uncultured Phage Genomes. Front. Microbiol. 2018, 9, 1033. [CrossRef]

86. Gondil, V.S.; Chhibber, S. Bacteriophage and Endolysin Encapsulation Systems: A Promising Strategy to Improve Therapeutic Outcomes. Front. Pharmacol. 2021, 12. [CrossRef] [PubMed]

87. Barreto, P.D.S.; Vellas, B.; Rolland, Y. Physical activity and exercise in the context of SARS-CoV-2: A perspective from geroscience field. Ageing Res. Rev. 2021, 66, 101258. [CrossRef] [PubMed]

88. Agu, R.U.; Ugwoke, M.I.; Armand, M.; Kinget, R.; Verbeke, N. The lung as a route for systemic delivery of therapeutic proteins and peptides. Respir. Res. 2001, 2, 198-209. [CrossRef]

89. Murray, E.; Draper, L.; Ross, R.; Hill, C. The Advantages and Challenges of Using Endolysins in a Clinical Setting. Viruses 2021, 13, 680. [CrossRef]

90. Furfaro, L.L.; Payne, M.S.; Chang, B.J. Bacteriophage Therapy: Clinical Trials and Regulatory Hurdles. Front. Cell. Infect. Microbiol. 2018, 8, 376. [CrossRef]

91. Love, M.J.; Bhandari, D.; Dobson, R.C.J.; Billington, C. Potential for Bacteriophage Endolysins to Supplement or Replace Antibiotics in Food Production and Clinical Care. Antibiotics 2018, 7, 17. [CrossRef] 